\title{
Genesis of the low-permeability reservoir bed of upper Triassic Xujiahe Formation in Xinchang gas field, western Sichuan Depression
}

\author{
Xu Zhangyou ${ }^{1,2} *$, Zhang Xiaoyu ${ }^{1}$, Wu Shenghe ${ }^{1,2}$ and Zhao Yan ${ }^{1}$ \\ ${ }^{1}$ School of Resources and Information Technology, China University of Petroleum, Beijing 102249, China \\ ${ }^{2}$ State Key Laboratory of Petroleum Resources and Prospecting, China University of Petroleum, Beijing 102249, China
}

\begin{abstract}
The genesis of a reservoir is a result of the combined action of deposition, diagenesis, tectonic reworking, and interaction of rock and fluid and the evolutionary environment. We discuss the genetic and evolution mechanism of a low-permeability reservoir bed of the Xujiahe Formation in the western Sichuan Depression on the basis of the study of diagenesis, diagenetic reservoir facies and the diagenetic evolution sequence. The research indicated that this reservoir bed can be divided into five types of diagenetic reservoir facies, namely strong dissolution, chlorite-lined intergranular pores, compaction and pressure solution, carbonate cementation and secondary quartz increase. There are, however, just two diagenetic reservoir facies which provide low-permeability reservoir beds, namely strong dissolution and chlorite-lined intergranular pores. We also analyzed their diagenetic evolution sequences and the origin of the low-permeability reservoir bed. Besides, it was also indicated that the composition and structure of sandstones, types of sedimentary microfacies, diagenesis history as well as the tectonic reworking in later periods are the main factors controlling the formation of the low-permeability reservoir bed. The abovementioned factors establish the foundation for the forecasting the distribution of high quality reservoir beds.
\end{abstract}

Key words: Low-permeability reservoir, diagenetic reservoir facies, Xujiahe Formation, upper Triassic, Xinchang gas field, western Sichuan Depression

\section{Introduction}

In the western Sichuan Depression, in the upper Triassic Xujiahe Formation thick bedded sandstone were deposited in blocks and medium-to-thick bedded siltstone in layers as well as finely laminated mudstone. There was a river delta depositional system in the Xujiahe Formation. In the Xinchang gas field of the western Sichuan Depression, the Xujiahe Formation is mainly braided river delta front subfacies. It is further divided into five sedimentary microfacies: underwater distributary channel, mouth bar, underwater interdistributary bay, distal bar and sand sheet. The reservoir beds of the Xujiahe Formation are mainly developed in the Xujiahe second member $\left(\mathrm{T}_{3} \mathrm{x}^{2}\right)$ and the Xujiahe fourth member $\left(\mathrm{T}_{3} \mathrm{x}^{4}\right)$. The varieties of sandstones primarily include litharenite, lithic quartzarenite, feldspathic lithic quartzarenite, lithic feldspathic quartzarenite, calcarenaceous sandstone. The sandstones in which gas might accumulate are litharenite, lithic quartzarenite, feldspathic lithic quartzarenite and calcarenaceous sandstone. The reservoir bed quality is characterized by low porosity and low

*Corresponding author. email: xzy@cup.edu.cn

Received March 12, 2008 permeability. The porosity is $1 \%-10 \%$ and the permeability is $0-5 \times 10^{-3} \mu \mathrm{m}^{2}$, so the reservoir bed is a super low-porosity and low- permeability one. Lü (2005), Zhu (1999), Zhu et al (2001) and Zeng et al (2005) think that sandstone is developed in the Xujiahe Formation, but relatively high quality reservoir beds are few. The distribution of sandstone is extremely non-uniform both areally and in the vertical direction. The advantageous reservoir beds are distributed throughout the thick sandstone in the vertical direction, and are controlled by sedimentary microfacies, diagenesis and fracture development caused by tectogenesis. As to the primary pores preservation, further analysis is needed as follows: 1) origin of chlorite growth; 2) the reason why the primary pores preservation of part of the Xujiahe second member is better than that of the Xujiahe fourth member, which is $1000 \mathrm{~m}$ shallower than the Xujiahe second member; 3) origin of primary pores growth in calcarenaceous sandstone; 4) the relationship between hydrocarbon infill and pores preservation. As to the formation of secondary porosity, further analysis is needed as follows: 1) the determination of the key dissolution phase amongst many dissolution phases; 2) the main controlling factor of denudation intensity; 3 ) the effective preservation of dissolution porosity. In this paper, we take the upper Triassic Xujiahe Formation in the Xinchang gas field, western Sichuan Depression as an example, then consider diagenetic reservoir 
facies as the key clue and discuss the genetic mechanism and controlling factors of the low-permeability reservoir beds in the Xujiahe Formation through an integrated study of sedimentary microfacies, lithogenesis and their diagenetic evolution sequences.

\section{Types and characteristics of diagenesis}

We examined 1219 cuttings samples, undertook 200 scanning electron microscope examinations of samples from 3 wells, and performed cathodoluminescence analysis on 54 samples of 3 wells of 8 coring key wells in the Xujiahe Formation. From this work we know that there are mainly three kinds of diagenesis, namely compaction and pressure solution, authigenic mineral cementation and dissolution in the formation process of the reservoir beds in $T_{3} x^{4}$ and $T_{3} x^{2}$.

\subsection{Compaction and pressure solution}

\subsubsection{Mechanical compaction}

Mechanical compaction in the Xujiahe fourth and second members mainly occurred in the early diagenetic phase, and the main manifestation is as follows: 1) The plastic deformation of plastic grains such as phyllite and mudstone etc.; 2) The flexural deformation, rupture and undulatory extinction of micaceous lamellar minerals; 3) The local breaking and dislocation of stiff grains, such as quartz and feldspar; 4) The contact intensity between the grains increases along with the enhancement of compaction, and the contact relationship is from point contact to line contact and from line contact to concave-convex contact.

\subsubsection{Pressure solution}

Pressure solution mainly occurred in the middle diagenetic phase. Dissolution occurred at the contact point or the contact interface of quartz particles and the dissolved silica was reprecipitated, which formed secondary enlargement of quartz or intergranular authigenic quartz. The grains assumed a mosaic-like structure to contact closely, which resulted in increasing compactness of the reservoir bed.

\subsection{Cementation}

The common cementing material in the reservoirs of the Xujiahe fourth and second members include carbonate, siliceous and clay minerals. The content of carbonate mineral is high, the siliceous mineral content is relatively high and clay mineral content is comparatively low.

\subsubsection{Carbonate mineral cementation}

Carbonate minerals are the most common and universal authigenic minerals in the Xujiahe Formation. The types of carbonate minerals include calcite, ferroan calcite, dolomite and ankerite, and their forms of occurrence are pores fillers or selective replacement of fragments.

1) Calcite: Early stage, calcite is non-ferroan. It fills intergranular pores with macrocrystalline, megacrysts or intergrowths, or replacement of the fragments. The precipitation temperature of calcite cement ranges approximately from $53^{\circ} \mathrm{C}$ to $66^{\circ} \mathrm{C}$ in the top of the Xujiahe fourth member, which was formed in the early diagenetic A phase. Late stage calcite fills intergranular pores and secondary dissolved pores with medium-crystalline and finely crystalline ferroan calcite. The formation temperatures of calcite from the isotopic temperature equation are $127.8^{\circ} \mathrm{C}$ and $104.9^{\circ} \mathrm{C}$, which was formed in the early stage of the late Jurassic and the last stage of the middle Jurassic, respectively. It is up to middle diagenetic B phase. The compound staining calcite is red, and ferroan calcite is mauve, while they cathodoluminescence crocus and yellowish-orange respectively.

2) Dolomite: Dolomite and ankerite fill pores with euhedral crystal to subhedral crystal, or replacement fragments. The compound staining ankerite is blue. The replacing ankerite surrounds the ferroan calcite, and does not cathodoluminescence. The precipitation temperature of dolomite cement ranges approximately from $117^{\circ} \mathrm{C}$ to $164^{\circ}$ $\mathrm{C}$ in the sandstone of the Xujiahe second member, which was formed in the middle diagenetic $\mathrm{A}$ and $\mathrm{B}$ phases.

\subsubsection{Siliceous cementation}

Four kinds of siliceous cement occur: 1) The edge of secondary enlargement, which shows no cathodoluminescence. The formation temperature of quartz at the secondary edge generally is $70^{\circ} \mathrm{C}$ to $88^{\circ} \mathrm{C}$, which was formed in the early diagenetic phase $\mathrm{B}$ and middle diagenetic phase $\mathrm{A} ; 2$ ) Filling residual intergranular pores, associated with chlorite or euhedral crystals of chlorite. It sometimes fills together with bitumen. The inclusion temperature of the filling quartz which was formed in the early diagenetic phase $\mathrm{B}$ in residual intergranular pores of the Xujiahe second member is $76^{\circ} \mathrm{C} ; 3$ ) Filling intragranular dissolved pores; 4) Filling intergranular dissolved pores. The kaolinite from the Xujiahe second member is mainly distributed below the $4000 \mathrm{~m}$ level. The kaolinite mainly exists in the reservoir beds of the Xujiahe fourth member, and is not found in thin section and scanning electron microscope examination of samples from the Xujiahe second member. The relative content of kaolinite is $11 \%-31 \%$ with hexagonal crystals, vermicular and book aggregation. It fills the intragranular dissolved pores and intergranular dissolved pores or adheres to particle surfaces in flake shaped. The kaolinite cathodoluminescences indigo under the microscope .

\subsubsection{Hydrosialite cementation}

X-diffraction analysis of samples from three wells X853, CX560 and CX565 shows the clay minerals of the Xujiahe fourth and Xujiahe second members mainly include illite with lesser chlorite. Kaolinite is mainly distributed in the Xujiahe fourth member, and there are slight illite/montmorillonite mixed-layers in other areas, with a mixed ratio less than $10 \%$.

1) Illite: It is widely distributed accounting for $26 \%-100 \%$ of clay minerals. Illite fills pore spaces or grows around particle edges with shapes of platy, needle, or cluster and replaces the fragments. Illite often grows in association with authigenic kaolinite and authigenic quartz, and it often grows on the surface of kaolinite in flake or needle shaped. The stability of illite is high, but the feldspar grains could dissolve to produce $\mathrm{Si}^{4+}, \mathrm{Al}^{3+}$ and $\mathrm{K}^{+}$which form illite, authigenic quartz and authigenic kaolinite in an acidic aqueous environment. The dissolution of K-feldspar in later periods may cause the environment to favor illite precipitation.

2) Chlorite: The absolute content of chlorite is low, generally less than $2 \%$ in this area, while its relative content is 
high, which is only less than illite. It accounts for $11 \%-74 \%$ of clay minerals (possibly including some land-derived chlorite). Authigenic chlorite includes two kinds of occurrences, namely pore lining and pore filler. The characteristics of pore lining chlorite are that crystals with acicular shape grows to the center of pore space in the direction vertical to the pore surface and then forms drusy texture. The crystal grows with micro-laminated shape and its pellicle is thin, whose thickness generally ranges from 2 to $10 \mu \mathrm{m}$, and a few are up to $15 \mu \mathrm{m}$. The characteristics of pore-filling chlorite are that a compound of chlorite and hydromica fills intergranular pores, and it often intergrows with authigenic quartz.

\subsection{Dissolution}

Any detrital grain, mixed matrix, cement and metasomatic mineral including most stable quartz and siliceous cement may dissolve under certain diagenetic environments. Dissolution is another key element which decides reservoir bed quality in the Xujiahe Formation. It can form secondary pores and improve the quality of the reservoir bed. The intragranular dissolved pores, intergranular dissolved pores and molding pores in this area are the results of dissolution. The most common phenomenon is the dissolution of feldspar, next is the dissolution of lithic fragments, quartz and interstitial matter. Secondary porosity caused by dissolution is the most important constructional diagenesis in the reservoir beds of the Xujiahe Formation.

The observation of cast sections shows that feldspar is dissolved in fenestra shapes. This forms intragranular dissolved pores. Some feldspar dissolves intensively, even dissolve completely to form molding pores. The dissolution of lithic fragments is rare and weak, and many lithic fragments dissolve partly, thus forming intragranular dissolved pores. In sandstones of the Xujiahe Formation, we can sometimes see some weak intragranular dissolution in quartz grains. Corroded authigenic quartz which fills intergranular pores is common as well as the corroded quartz fringe or solution quartz. After the analysis of thin sections and scanning electron microscopy, we know that the dissolution of the Xujiahe second member is weak, and is obviously weaker than that of the Xujiahe fourth member.

\section{Diagenetic reservoir facies}

The concept of diagenetic reservoir facies of reservoir beds has experienced more than ten years of development since it was proposed (Xiong et al, 1991; 1994; Xiong, 1993). Different scholars have done fruitful research from different perspectives in different areas. These include Xu et al, 1994a; 1994b; Liu et al, 2002; Huang and Dou, 2002; Song et al, 2004; Li et al, 2004; Li and Peng, 2007a; 2007b; Song et al, 2006; 2007; Zhou et al, 2006; Xue et al, 2006; Xue and Cheng, 2007 and Zou et al, 2007. Research on diagenetic reservoir facies has developed quickly in recent years, and has become an important domain in the reservoir bed research. According to petrologic characteristics, sedimentary microfacies, diagenesis types, apparent compaction rate, apparent cementation rate, diagenesis coefficient, combination of reservoir space, porosity, permeability and so on, the reservoir beds of the Xujiahe Formation can be divided into five categories of diagenetic reservoir facies. As shown in Table 1, they are named as follows: strong dissolution, chlorite-lined intergranular pores, compaction and pressure solution, carbonate cementation and secondary quartz increase. In these facies, only strong dissolution and chloritelined intergranular pores are conducive to the formation of relatively high quality reservoir beds.

\section{Characteristics of diagenetic evolution sequences}

Diagenetic evolution is the dynamic modality in a diagenetic process (Zhang et al, 1997; Alaa M et al, 2000; Liu and Dou, 2003; Zhu et al, 2004; Liu et al, 2005; Jiang et al, 2007). It is the manifestation of burial depth, geothermal gradient, tectonic setting, types of sedimentary facies, diagenetic media condition and other factors. Through the diagenetic evolution sequence, we can sum up the evolutionary trend, evolutionary method and evolutionary result of diagenetic reservoir facies in the process of diagenesis. Different diagenetic reservoir facies have different diagenetic evolution sequences. In this article, we only elaborate the diagenetic evolution sequences of two kinds of diagenetic reservoir facies which are the typical representatives of the Xujiahe second member and the Xujiahe fourth member.

\subsection{Diagenetic evolution sequence of strong dissolution}

According to the observation of the characteristics under the optical microscope and a scanning electron microscope, cathodoluminescence observation and inclusion homogenization temperature, we think that the relative order of the main diagenetic events in strong dissolution diagenetic reservoir facies can be identified as follows (Fig. 1): chlorite liner $\rightarrow$ early corrosion by atmospheric freshwater $\rightarrow$ authigenic kaolinite $\rightarrow$ secondary enlargement $\rightarrow$ acidic dissolution of coal measure strata $\rightarrow$ authigenic quartz (intergranular vugular-solution pores, intragranular vugular-solution pores) $\rightarrow$ calcite and dolomite $\rightarrow$ organic matter maturation acidic water solution $\rightarrow$ authigenic quartz $\rightarrow$ ferroan calcite and dolomite. Rock types mainly are feldspathic lithic arenite and lithic arkose. Original rocks with a high content of feldspar and lithic fragments have better sorted, low-level matrix content, point to line particle contact, and moderate-strong compaction. Intergranular cements are mainly quartz, a small amount of chlorite and kaolinite. With strong dissolution, soluble components commonly dissolved to form all kinds of secondary dissolution pores, feldspar partly dissolved to form intragranular dissolution pores, and completely dissolved to form molding pores, and intergranular matrix, cement and particulate margin dissolved to form intergranular dissolution pores or super large dissolution pores. Reservoir spaces are mainly secondary dissolution pores, as well as the combination of intragranular dissolution pores, intergranular dissolution pores, molding pores, super large dissolution pores and caulking intergranular micropores. 
Strong dissolution diagenetic reservoir facies forms the best reservoir beds in the region, in which porosity is more than $7 \%$, and permeability ranges from 0.05 to $0.5 \times 10^{-3} \mu \mathrm{m}^{2}$. Microfacies are mainly mouth bar, secondly underwater distributary channel, all of which are mainly distributed in the Xujiahe fourth member.

\subsection{Diagenetic evolution sequence of chlorite-lined intergranular pores}

Different from strong dissolution diagenetic reservoir facies, the relative order of the main diagenetic events of chlorite-lined intergranular pores diagenetic reservoir facies can be identified as follows (Fig. 2): chlorite pore lining $\rightarrow$ quartz secondary enlargement $\rightarrow$ acidic dissolution of coal measure strata $\rightarrow$ authigenic quartz (quartz is filled in residual intergranular pores) $\rightarrow$ late carbonate cementation (mainly dolomite, calcite next) $\rightarrow$ organic matter mature acidic water solution $\rightarrow$ authigenic quartz (cave type, oversized pore type) $\rightarrow$ late alkaline water erosion and so on. Rock types are mainly lithic quartzitic sandstones. Original rocks with a high content of quartz, feldspar and other rigid particles have better sorted, low-level matrix content, point to line particle contact and moderate-strong compaction. On the margin of the original intergranular pores, there was chloritelining, and the pores became narrow after compaction, then authigenic quartz filled the pores, and late quartz dissolved into intergranular cement dissolution pores. With moderate dissolution, soluble components commonly dissolved to form secondary dissolution pores, feldspar and lithic fragments dissolved to form intragranular dissolution pores, and intergranular matrix, cement and particulate margin dissolved to form intergranular dissolution pores. Reservoir spaces are mainly intergranular dissolution pores and micro-cracks, as well as a small amount of residual intergranular pores and intragranular dissolution pores. Chlorite-lined intergranular pores diagenetic reservoir facies is the better reservoir bed in the region, and its porosity is more than $4 \%$ and permeability ranges from 0.05 to $0.5 \times 10^{-3} \mu \mathrm{m}^{2}$. Microfacies are mainly

Table 1 Types and characteristics of diagenetic reservoir facies of Xujiahe Formation in the Xinchang gas field

\begin{tabular}{|c|c|c|c|c|c|}
\hline Diagenetic reservoir facies & $\begin{array}{c}\text { Strong dissolved } \\
\text { diagenetic reservoir } \\
\text { facies }\end{array}$ & $\begin{array}{c}\text { Chlorite-lined } \\
\text { intergranular pores } \\
\text { diagenetic reservoir } \\
\text { facies }\end{array}$ & $\begin{array}{c}\text { Compaction and } \\
\text { pressure solution } \\
\text { diagenetic reservoir } \\
\text { facies }\end{array}$ & $\begin{array}{c}\text { Carbonate } \\
\text { cementation } \\
\text { diagenetic reservoir } \\
\text { facies }\end{array}$ & $\begin{array}{l}\text { Secondary quartz } \\
\text { increase diagenetic } \\
\text { reservoir facies }\end{array}$ \\
\hline Rock types & $\begin{array}{c}\text { Feldspathic litharenite } \\
\text { Lithic arkose }\end{array}$ & Lithic quartzarenite & Litharenite & $\begin{array}{l}\text { Feldspathic } \\
\text { litharenite } \\
\text { Lithic arkose }\end{array}$ & $\begin{array}{c}\text { Feldspathic lithic } \\
\text { quartzarenite } \\
\text { Feldspathic } \\
\text { quartzarenite } \\
\end{array}$ \\
\hline $\begin{array}{c}\text { Contact relationship } \\
\text { between particles }\end{array}$ & Point-line contact & Point-line contact & Pressure-inlay & $\begin{array}{c}\text { Point contact } \\
\text { Pore-cementation }\end{array}$ & Pressure-inlay \\
\hline Main microfacies & $\begin{array}{l}\text { Mouth bar } \\
\text { Distributary channel }\end{array}$ & $\begin{array}{l}\text { Mouth bar } \\
\text { Distributary channel }\end{array}$ & $\begin{array}{c}\text { Distal bar } \\
\text { Sand sheet } \\
\text { Interdistributary bay }\end{array}$ & $\begin{array}{c}\text { Distributary channel } \\
\text { Interdistributary bay } \\
\text { Distal bar } \\
\text { Sand sheet }\end{array}$ & $\begin{array}{c}\text { Distributary } \\
\text { channel } \\
\text { Distal bar } \\
\text { Sand sheet }\end{array}$ \\
\hline Main diagenesis & Dissolution & $\begin{array}{c}\text { Chlorite-lined } \\
\text { cementation } \\
\text { Quartz dissolution in } \\
\text { intergranular pore }\end{array}$ & $\begin{array}{c}\text { Compaction } \\
\text { Pressure solution }\end{array}$ & $\begin{array}{l}\text { Carbonate } \\
\text { cementation } \\
\text { metasomatism }\end{array}$ & $\begin{array}{l}\text { Quartz secondary } \\
\text { enlargement } \\
\text { Autogenic quartz } \\
\text { filling }\end{array}$ \\
\hline Secondary diagenesis & $\begin{array}{l}\text { Compaction } \\
\text { Cementation }\end{array}$ & $\begin{array}{l}\text { Compaction } \\
\text { Cementation }\end{array}$ & Cementation & Compaction & $\begin{array}{l}\text { Compaction } \\
\text { Cementation }\end{array}$ \\
\hline $\begin{array}{c}\text { Apparent compaction rate } \\
\%\end{array}$ & $60-70$ & $70-90$ & $>90$ & $<40$ & $70-90$ \\
\hline $\begin{array}{c}\text { Apparent cementation rate } \\
\%\end{array}$ & $10-30$ & $30-50$ & $<20$ & $>50$ & $<20$ \\
\hline $\begin{array}{c}\text { Diagenesis coefficient } \\
\%\end{array}$ & $>2$ & $1-4$ & $<1$ & $<1$ & $<1$ \\
\hline $\begin{array}{l}\text { Reservoir space } \\
\text { composition }\end{array}$ & $\begin{array}{c}\text { Intergranular pores } \\
\text { Intragranular pores } \\
\text { Molding pores } \\
\text { Super dissolved pores } \\
\text { Interstitial material } \\
\text { between the } \\
\text { microporous } \\
\text { crystalline } \\
\end{array}$ & $\begin{array}{c}\text { Intergranular cement } \\
\text { dissolved pores } \\
\text { Residual intergranular } \\
\text { pores } \\
\text { Intragranular } \\
\text { dissolved pores } \\
\text { Microfracture }\end{array}$ & $\begin{array}{c}\text { A very small amount of } \\
\text { intragranular dissolved } \\
\text { pores }\end{array}$ & $\begin{array}{c}\text { A very small amount } \\
\text { of intragranular } \\
\text { dissolved pores }\end{array}$ & $\begin{array}{l}\text { A very small } \\
\text { amount of } \\
\text { intragranular } \\
\text { dissolved pores }\end{array}$ \\
\hline Porosity, \% & $>7$ & $>4$ & $<2.0$ & $<2.0$ & $<2.0$ \\
\hline Permeability, $\times 10^{-3} \mu \mathrm{m}^{2}$ & $0.05-0.5$ & $0.05-0.5$ & $<0.008$ & $<0.008$ & $<0.008$ \\
\hline Reservoir performance & Reservoir & Reservoir & Dense layer & Dense layer & Dense layer \\
\hline
\end{tabular}




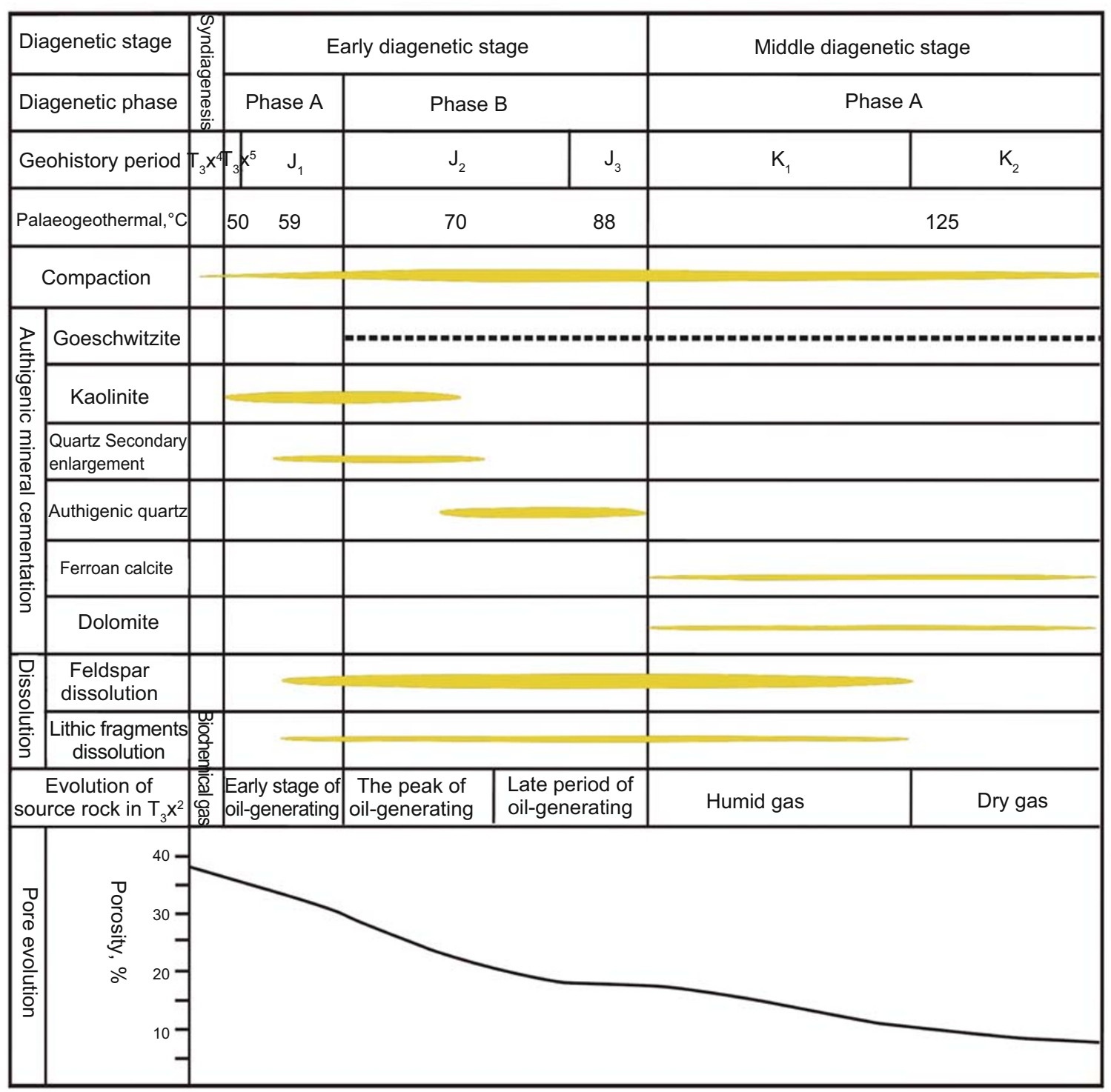

Fig. 1 Diagenetic evolution sequence of strong dissolved diagenetic reservoir facies

mouth bar, secondly underwater distributary channel, all of which are mainly distributed in the Xujiahe second member.

\section{Discussions}

Through the investigation of cuttings from key wells in the Xujiahe Formation with optical microscopy, scanning electron microscopy and cathodoluminescence analysis, we think that there are mainly three kinds of diagenesis, namely compaction and pressure solution, authigenic mineral cementation, and dissolution in the Xinchang gas field during the formation process of the reservoir bed.

During the early diagenetic stage, grain contact in the reservoir bed is point contact first, then line contact, last concavo-convex contact with stronger and stronger mechanical compaction. Therefore, the intergranular porosity decreases and the reservoir bed becomes tight. In the middle diagenetic stage, pressure solution is the main diagenesis, dissolved matter is carried from the grain contact point by diffusion, and the arrangement mode of grains ranges from point/line contact to concavo-convex/suture contact with increasing burial depth. After compaction, there are many types of diagenesis, such as carbonate cementation, siliceous cementation and clay mineral cementation in the intergranular pores space of clastic grains. Owing to the cementation, sediments in the reservoir bed further transformed to sedimentary rocks, resulting in decreasing intergranular space, which caused poor reservoir quality. After compaction and pressure solution as well as autogenic mineral cementation, clastic grain, miscellaneous matrix, cement material and replacement minerals dissolved in different degrees and formed intragranular pores, intergranular pores, molding pores and so on, which resulted in the growth of secondary porosity, and thus improved the quality of the reservoir bed to a certain extent.

From the diagenetic features mentioned above, we conclude that mechanical compaction, pressure solution and cementation could decrease porosity and permeability with increasing burial depth. The inhomogeneous corrosion and dissolution could generate some secondary pores, even generate induced pores development belts at different depths, 


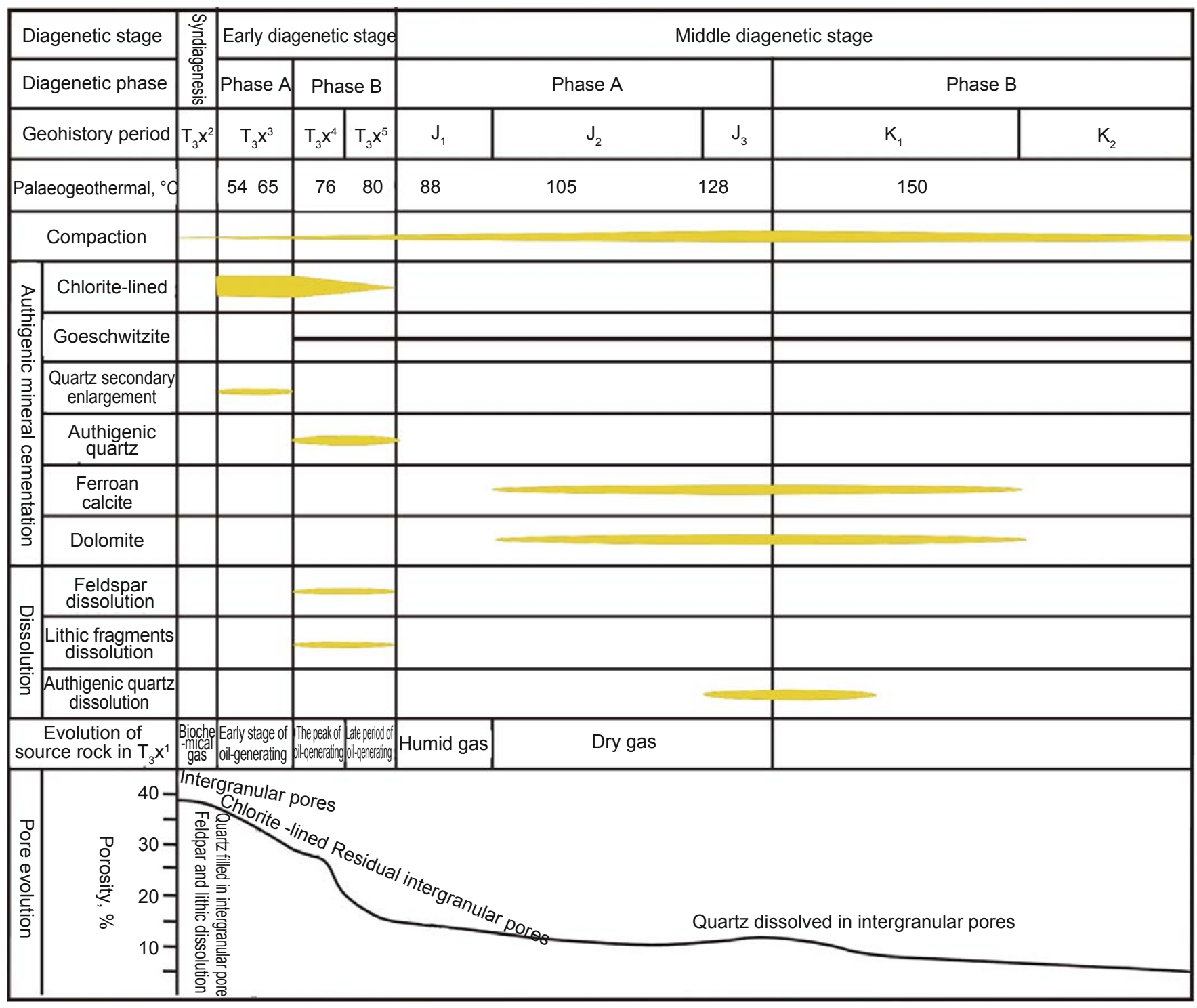

Fig. 2 Diagenetic evolution sequence of chlorite-lined intergranular pores diagenetic reservoir

and thus improved the quality of the reservoir bed. In general, diagenesis mainly influenced the reservoir quality in two ways: first, compaction decreased reservoir bed porosity and worsened reservoir bed quality; second, dissolution generated secondary pores, which increased reservoir bed porosity and improved reservoir bed quality.

According to the genesis and evolutionary mechanisms of low-permeability reservoirs described above, we conclude that the controlling factors of low-permeability reservoirs mainly comprise the structure and composition of sandstone, sedimentary microfacies, diagenesis and tectonization.

\subsection{Structure and composition of sandstone are the basis of forming low-permeability reservoir beds}

From the influence of the composition and structure of sandstones, the main factors which affect the quality of a reservoir bed are composition, size grade and sorting (Shou et al, 2006). When the content of a stable component that is to say quartz increases and the sandstone's component maturity increases and matrix and cement is eliminated greatly after long-distance transportation. Because of relatively concentrated quartz, preferable gradation and psephicity of grains and higher textural maturity, this environment is favorable for forming a high quality reservoir bed. But when the content of an unstable component, i.e. feldspar or lithic fragments, is high, which means sandstone's component maturity is low, matrix and cement is still present in large amount after transportation. Owing to the complexity of the arenite's mineral component, disaggregation of quartz, poorly rounded and poorly sorted, and lower textural maturity, it is easy to form low-permeability reservoir beds.

Through analysis, we know that the main rock types of the Xujiahe Formation are quartz sandstone and lithic quartz sandstone. The quartz content is between $60 \%$ and $90 \%$, the feldspar content is $2 \%-6 \%$, the lithic fragments content is $10 \%-40 \%$, and the interstitial material content is $2 \%-12 \%$. In this area, the mineral composition is complex, and the compositional maturity of sandstone is low. The sandstone granularity of the reservoir bed is mainly from medium-grained sand to fine sand, the particle sorting is 
ordinary, psephicity is mainly subangular shape and the textural maturity of sandstones is low. From the structure and composition, we can see that the reservoir bed of the Xujiahe Formation does not have the material condition of high porosity and high permeability. But the presence of lithic fragments at a relatively high concentration provides the material base of lyotrope for the late occurrence of advantageous diagenesis and provides the effective accommodation space for the formation of secondary pores. Thus it is advantageous for the formation of a lowpermeability reservoir bed.

\subsection{Types of sedimentary microfacies are the conditions of forming low-permeability reservoir beds}

Sedimentary microfacies play an important role on the development and distribution of reservoir rocks. It not only constrains the thickness and scale of reservoir and spatial distribution characteristics macroscopically, but also determines the particle size of sedimentary rocks, the amount of interstitial content and the quality of the rock structure from a microscopic aspect. Thus it controls the quality of the rock's original porosity and original permeability.

\subsection{Diagenesis is the internal cause of forming low- permeability reservoir beds}

Diagenesis plays a key role in the formation, destruction and reconstruction of porosity and permeability during the formation and evolution process of the low-permeability reservoir bed. Cementation, compaction and pressure solution resulted in stronger surface durability of clastic particles, and destroyed the original porosity of the reservoir bed. Thus it made the reservoir bed tight and poor. But dissolution formed secondary pores in certain diagenetic environments, which increased the intergranular porosity and its communication. Then the quality of the reservoir bed could be improved.

Through the analysis of diagenetic reservoir facies, we think that the distribution of effective diagenetic reservoir facies (strong dissolution and chlorite-lined intergranular pores) is tightly controlled by sedimentary microfacies in the Xujiahe Formation. Also, strong dissolution diagenetic reservoir facies is only confined to the river mouth bar and distributary channel microfacies. Chlorite-lined intergranular pores diagenetic reservoir facies belongs to river mouth bar, in which the middle basic magmatic rocks and the dark color ferromagnesian minerals are abundant. Owing to the transportation of the dissolved iron deposits in the delta front river mouth bar, chlorite sedimentation occurred.

Strong dissolution diagenetic reservoir facies is developed in $\mathrm{T}_{3} \mathrm{x}^{4}$ whose dissolution is stronger than that in $\mathrm{T}_{3} \mathrm{x}^{2}$. But the burial depth of $\mathrm{T}_{3} \mathrm{x}^{2}$ is deeper than that of $\mathrm{T}_{3} \mathrm{x}^{4}$ whose last diagenetic stage is the diagenetic period of middle A. At the same time, some layers of $\mathrm{T}_{3} \mathrm{x}^{2}$ have entered the diagenetic period of middle $\mathrm{B}$.

\subsection{Tectonism is the favorable factor of reforming low-permeability reservoir bed}

Fractures are developed in the reservoir beds of the
Xujiahe Formation due to multi-phase tectonic action. But fracture distribution is extremely non-uniform. The crack growth is different in different structures and locations due to structure deformation intensity and fault growth. In the anticlinal belt and break growth belt of structural high, massive high-angle cracks in calcarenaceous sandstone favored reservoir bed growth. It both increased reservoir space and improved permeability, and also opened the oil and gas migration path. Thus it improved the accumulation performance of the low permeability reservoir bed.

\section{Acknowledgments}

This paper was supported by CNPC Innovation Foundation (07E1002). During our research, we obtained instructions and help from two senior staff geologists, Ye Jun and Lü Zhengxiang of Research Institute of Exploration and Development, SINOPEC Southwest Company. Many thanks are due to Professor Jiang Panliang of China University of Petroleum (Beijing), for his foundation work. A brief thank you to Johan Christie for quickly reviewing our text in English.

\section{References}

Alaa M, Salem S and Moead S. Diagenesis and reservoir-quality evolution of fluvial sandstones during progressive burial and uplift: evidence from the Upper Jurassic Boipeba Member, Revoncavo basin, northeastern Brazil. AAPG Bulletin. 2000. 84(7): 1015-1040

Huang S W and Dou Q F. Characteristics of diagenesis reservoir facies and pore space evolution of the second member of Quantou Formation in Siwujiazi Oilfield, Jilin Province. Earth ScienceJournal of China University of Geosciences. 2002. 27(6): 723-728 (in Chinese)

Jiang L Z, Gu J Y and Guo B C. Characteristics and genetic mechanism of low-permeability reservoir of clastic rock in oil and gas bearing basin, China. Acta Sedimentologica Sinica. 2007. 22(1): 13-18 (in Chinese)

Li H Y, Peng S M, Huang S W, et al. Diagenetic reservoir facies of low permeability reservoir of the second and third members of Shahejie Formation of Paleogene in Bonan oil field, Shandong Province. Journal of Paleogeography. 2004. 6(4): 503-513 (in Chinese)

Li H Y and Peng S M. Characteristics of diagenetic-reservoir facies of low-permeability reservoir in Sulige gas field. Acta Petrolei Sinica. 2007a. 28(3): 100-104 (in Chinese)

Li H Y and Peng S M. Diagenetic reservoir facies and pore space evolution pattern of low-permeability reservoir. Journal of china University of Petroleum (Edition of Natural Science). 2007b. 31(5): 1-6 (in Chinese)

Liu C L, Zhu X M and Zeng Q M. Reservoir diagenetic sequence and pores evolution of Sulige gas field. Natural Gas Industry. 2005. 25(11): 1-3 (in Chinese)

Liu W and Dou Q F. Study on diagenesis and diagenetic-reservoir facies of the lower member of $\mathrm{J}_{3 \mathrm{ff}}$ of Jiao 2 block in Keerqin oil field. Journal of $\mathrm{Xi}^{\prime}$ an Petroleum Institute (Natural Science Edition). 2003. 18(3):6-8 (in Chinese)

Liu W, Dou Q F, Huang S W, et al. Quantitative characterization of diagenesis and research of diagenesis reservoir facies - the case study of lower member of $\mathrm{J}_{3 \mathrm{j} f}$ of Jiao2 block in Kerqin oil field. Journal of China University of Mining and Technology. 2002. 31(5): 399-405 (in Chinese)

Lü Z X. Evolutionary characteristics of Upper Triassic reservoir in Xiaoquan structure in West Sichuan, China. Journal of Chengdu 
University of Technology (Science \& Technology Edition). 2005. 32(1): 22-26 (in Chinese)

Shou J F, Si C S and Wang X. Genesis types and diagenesis compaction mechanisms of sandstone reservoirs in dynamic environments in oil/ gas basins in China. Petroleum Science. 2006. 3(3): 23-31

Song C H, Li X, Chen J, et al. Diagenetic-reservoir facies division of reservoir. Natural Gas Industry. 2004. 24(10): 27-29 (in Chinese)

Song z Q, wang $\mathrm{j}$, lu x W, et al. Quantitative evaluating method of diagenesis-reservoir facies of low permeability reservoir. petroleum geology and recovery efficiency. 2006. 13(2): 21-24 (in Chinese)

Song Z Q, Yu X L, Ding J, et al. Comprehensive evaluation of diagenetic reservoir facies by gray theory. Special Oil and Gas Reservoir. 2007. 14(1): 26-29 (in Chinese)

Xiong Q H, Peng S M, Huang S W, et al. A preliminary study of the new concept of petrophysical facies and its initial application in Lengdong-Leijia region in Liaohe Depression. Acta Petrolei Sinica. 1994. 15: 68-75 (in Chinese)

Xiong Q H, Yao M, Xu Z Y, et al. Comprehensive evaluation of reservoir in Zaonan Kong 1 and Kong 2 members of Zaoyuan oil field (Scientific research report). 1991 (in Chinese)

Xiong Q H. Description of petroleum pool and comprehensive evaluation of reservoir in Zaoyuan oil field (Scientific research report). 1993 (in Chinese)

Xu Z Y, Wei P and Xiong Q H. The diagenesis and diagenetic facies of $E_{1}-E_{2}$ in South Zaoyuan oil field. Acta Petrolei Sinica. 1994a. 15: 60-66 (in Chinese)

Xu Z Y, Wei P and Xiong Q H. Diagenesis and pores evolution models of Kongdian Formation in south Zaoyuan oil field. Journal of China University of Petroleum (Edition of Natural Science). 1994b. 19(1): 7-12 (in Chinese)
Xue Y C, Cheng L S and Peng S M. Study on diagenesis and diagenetic reservoir facies of the third and fourth members of Quantou Formation in Xinli Oilfield. Special Oil and Gas Reservoir. 2006. 13(2): 19-23 (in Chinese).

Xue Y C and Cheng L S. Study on diagenesis-reservoir facies of Fuyang reservoir in Xinli Oilfield. petroleum geology and development of Daqing. 2007. 26(1): 22-26 (in Chinese)

Zhang Y W, Xiong Q H, Wu S H, et al. Terrestrial reservoir description. Beijing: Petroleum Industry Press. 1997. 103-117 (in Chinese)

Zeng L B, Wang Z G and Zhang G B. A comprehensive evaluation method for low-permeability reservoirs. Petroleum Science. 2005. 2(4): 9-13

Zhu T. Control of diagenesis on the tight sand reservoirs -taking the gas reservoir of Upper Shaximiao Formation in Xinchang gas field, Western Sichuan Basin as an example. Institute of Southwest Petroleum Bureau. 1999. 26(2): 157-160 (in Chinese)

Zhu T, Ye J and Wang S C. Division and identification marks of poolforming environment in Xinchang gasfield of the west Sichuan Depression. Petroleum Geology and Experiment. 2001. 23(2): 174-182 (in Chinese)

Zhu X M, Zhong D K, Zhang Q, et al. Sandstone diagenesis and porosity evolution of Paleogene in Huimin depression. Petroleum Science. 2004. 1(3): 23-29

Zhou H T, Peng S M and Li H Y. Diagenetic reservoir facies and pore space evolution of low-permeability reservoir in Shaxi oil field. Coal Geology and Exploration. 2006. 34(6): 22-26 (in Chinese)

Zou C N, Hou L H, Kuang L C, et al. Genetic mechanism of diagenesisreservoir facies of fan-controlled permo-triassic in the western marginal area, Jungger Basin. Chinese Journal of Geology. 2007. 42(3): 587-601 (in Chinese) 